\title{
Clinicopathological Features and Prognostic Implications of Immunophenotypic Subgroups in Childhood ALL: Experience of the BFM-ALL Study 83*
}

\author{
W.-D. Ludwig ${ }^{1}$, H. Seibt-Jung ${ }^{1}$, J.V. Teichmann ${ }^{1}$, B. Komischke ${ }^{1}$, A. Gatzke ${ }^{1}$, \\ G. Gassner ${ }^{1}$, E. Odenwald ${ }^{2}$, J. Hofmann ${ }^{2}$, and H. Riehm ${ }^{2}$
}

\section{A. Introduction}

The application of immunological marker studies to acute lymphoblastic leukemias (ALL) has established a solid basis for precise diagnosis and classification [1] and, in combination with enzymatic, cytogenetic, and molecular analyses [2-4], has helped to unravel a great deal of the biological heterogeneity of childhood ALL.

Up to now, investigations examining the impact of the immunophenotype on treatment outcome have mostly reported results based upon conventional marker studies and have indicated a worse prognosis for children with pre-B, B-, and Tlineage ALL [5-8]. Due to the paucity of controlled prospective studies on clinical and prognostic implications of immunophenotypes, however, doubts have arisen regarding the value of the immunophenotype as an independent prognostic parameter in ALL [9]. Furthermore, the improvement of intensive therapy has affected the prognostic importance of most clinical and biological features in childhood ALL [10].

Therefore, the main objective of immunological marker studies in the therapy study ALL-BFM 83 was to determine prospectively the incidence, the clinical and hematological features, and the

\footnotetext{
* Supported in part by the Deutsche Krebshilfe and DAL/GPO

1 Department of Hematology/Oncology, Klinikum Steglitz, Free University of Berlin, Federal Republic of Germany

2 Department of Pediatrics, Hannover Medical School, Hannover, Federal Republic of Germany
}

prognostic significance of immunophenotypic subgroups defined by monoclonal antibodies (MoAbs) in childhood ALL.

\section{B. Materials and Methods \\ I. Patients}

From October 1983 to September 1986, 709 previously untreated children with ALL were stratified for risk-adapted multidrug chemotherapy in the ALLBFM 83 multicenter trial [11]. Complete immunophenotypic determinations were performed in $607(85.6 \%)$ of these patients.

\section{Immunophenotyping}

Leukemic blasts from bone marrow and/ or peripheral blood samples were isolated by Ficoll-Hypaque density gradient centrifugation. The following were performed as described elsewhere [12, 13]: a standard indirect immunofluorescence assay for detection of cell-surface antigens and conventional marker studies, including determination of surface immunoglobulin, sheep erythrocyte rosettes, and intranuclear terminal deoxynucleotidyl transferase. A marker was considered positive if reactive with $\geq 20 \%$ of leukemic blast cells.

\section{Monoclonal Antibodies}

The following MoAbs from cluster of differentiation (CD) groups defined by the International Workshops on Leukocyte Differentiation Antigens were used for immunophenotyping: (a) B-lineage- 
associated antigens: HD37 (CD19) (B. Dörken, Heidelberg), B1 (CD20) (Coulter Clone, Hialeah, FL), VIB-C5 (CD24) (W. Knapp, Vienna); (b) T-lineage-associated antigens: Na1/34 (CD1) (SeraLab), OKT11 (CD2), OKT3 (CD3), OKT4 (CD4), OKT8 (CD8) (Orthodiagnostic Systems, Raritan, NJ), Leu-9 (CD7) (Becton Dickinson, Sunnyvale, CA); (c) myeloid-lineage-associated antigens: VIM-2 (CDw65), VIM-D5 (CD15) (W. Knapp, Vienna), My9 (CD33) (Coulter Clone); (d) non-lineage-restricted antigens: OKIa1 (not clustered) (Orthodiagnostic Systems), J5 (CD10) (Coulter Clone).

\section{Statistical Analysis}

All $P$-values resulted from two-sided tests. The method of Kaplan and Meier [14] was used to construct the life-tables plotted in Figs. 1, 2, and 3. Comparisons of event-free survival (EFS) were calculated by the log-rank test [15]. Multivariate analyses were performed in a forward stepwise fashion, using the Cox regression model to analyze the importance of prognostic factors in influencing the duration of continuous complete remission [16].

\section{Results}

\section{Treatment Outcome}

Patients were classified according to their phenotypic profile into the following subgroups: null ALL, common ALL, BALL, pre-T-ALL, T-ALL. Three patients were unclassifiable by immunophenotypic analysis. The vast majority of children with ALL achieved complete remission (CR) (Table 1). The common ALL group had a significantly longer EFS after a median 27-month follow-up than children with pre-T/T-ALL and BALL (Fig. 1). The patients with null ALL, though only a small series in this study, appeared to have an intermediate remission duration (Fig. 1). Further subclassification of the common ALL group revealed significant differences between the $\mathrm{CD} 20^{-}$and the $\mathrm{CD} 20^{+}$patients, indicating that EFS was as poor for children with $\mathrm{CD} 20^{+}$common ALL as for those with pre-T/T-ALL (Fig. 2).

Immunophenotypic subgroups in $\mathrm{T}$ lineage ALL (pre-T ALL vs. early vs. cortical vs. mature T-ALL) (Fig. 3) as well as $\mathrm{CD} 10^{+}$vs. $\mathrm{CD} 10^{-}$pre-T/T-ALL patients (data not shown) disclosed no significant differences with regard to EFS.

Table 1. Definition and distribution of immunophenotypic subgroups and their response to induction therapy among children with ALL in the ALL-BFM study 83

\begin{tabular}{|c|c|c|c|}
\hline $\begin{array}{l}\text { Immuno- } \\
\text { logical } \\
\text { diagnosis }\end{array}$ & Immunophenotype & $\begin{array}{l}\text { No. of } \\
\text { patients } \\
(\%)\end{array}$ & $\begin{array}{l}\text { Percent } \\
\mathrm{CR}^{\mathbf{a}}\end{array}$ \\
\hline Null ALL & 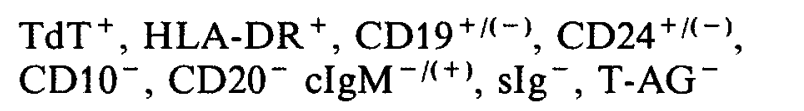 & $21 \quad(3.5)$ & 100 \\
\hline Common $\mathrm{ALL}^{\mathrm{b}}$ & $\begin{array}{l}\mathrm{TdT}^{+}, \mathrm{HLA}_{-\mathrm{DR}}^{+}, \mathrm{CD} 19^{+}, \mathrm{CD}_{24^{+}}, \mathrm{CD}_{10^{+}}, \\
\mathrm{CD} 20^{-1+}, \mathrm{cIgM}^{-1+}, \mathrm{sIg}^{-}, \mathrm{T}_{-\mathrm{AG}^{-}}\end{array}$ & $481 \quad(79.6)$ & 99.2 \\
\hline B-ALL & $\begin{array}{l}\mathrm{TdT}^{-}, \mathrm{HLA}-\mathrm{DR}^{+}, \mathrm{CD}_{19^{+}}, \mathrm{CD}_{24^{+}}, \mathrm{CD} 20^{+}, \\
\mathrm{CD}^{+} 0^{+/-}, \mathrm{cIgM}^{-}, \mathrm{sIg}^{+}, \mathrm{T}_{-\mathrm{AG}^{-}}\end{array}$ & $11 \quad(1.8)$ & 90.9 \\
\hline Pre-T ALL & $\begin{array}{l}\mathrm{TdT}^{+}, \mathrm{HLA}_{-\mathrm{DR}}^{-1(+)}, \mathrm{CD}^{+}, \mathrm{CD}^{+/(-)} \\
\mathrm{CD} 2^{-}, \mathrm{CD} 1 / 3 / 4 / 8^{-}, \mathrm{CD} 10^{-1+}, \mathrm{B}-\mathrm{AG}^{-}\end{array}$ & $(3.0)$ & 94.4 \\
\hline T-ALL & $\begin{array}{l}\mathrm{TdT}^{+}, \mathrm{HLA}^{-} \mathrm{DR}{ }^{-}, \mathrm{CD}^{+}, \mathrm{CD}^{+}, \mathrm{CD} 2^{+} \\
\mathrm{CD} 1 / 3 / 4 / 8^{+1-}, \mathrm{CD} 10^{-1+}, \mathrm{B}_{-} \mathrm{AG}^{-}\end{array}$ & $73 \quad(12.1)$ & 95.9 \\
\hline Total & & $604(100.0)$ & 98.3 \\
\hline
\end{tabular}




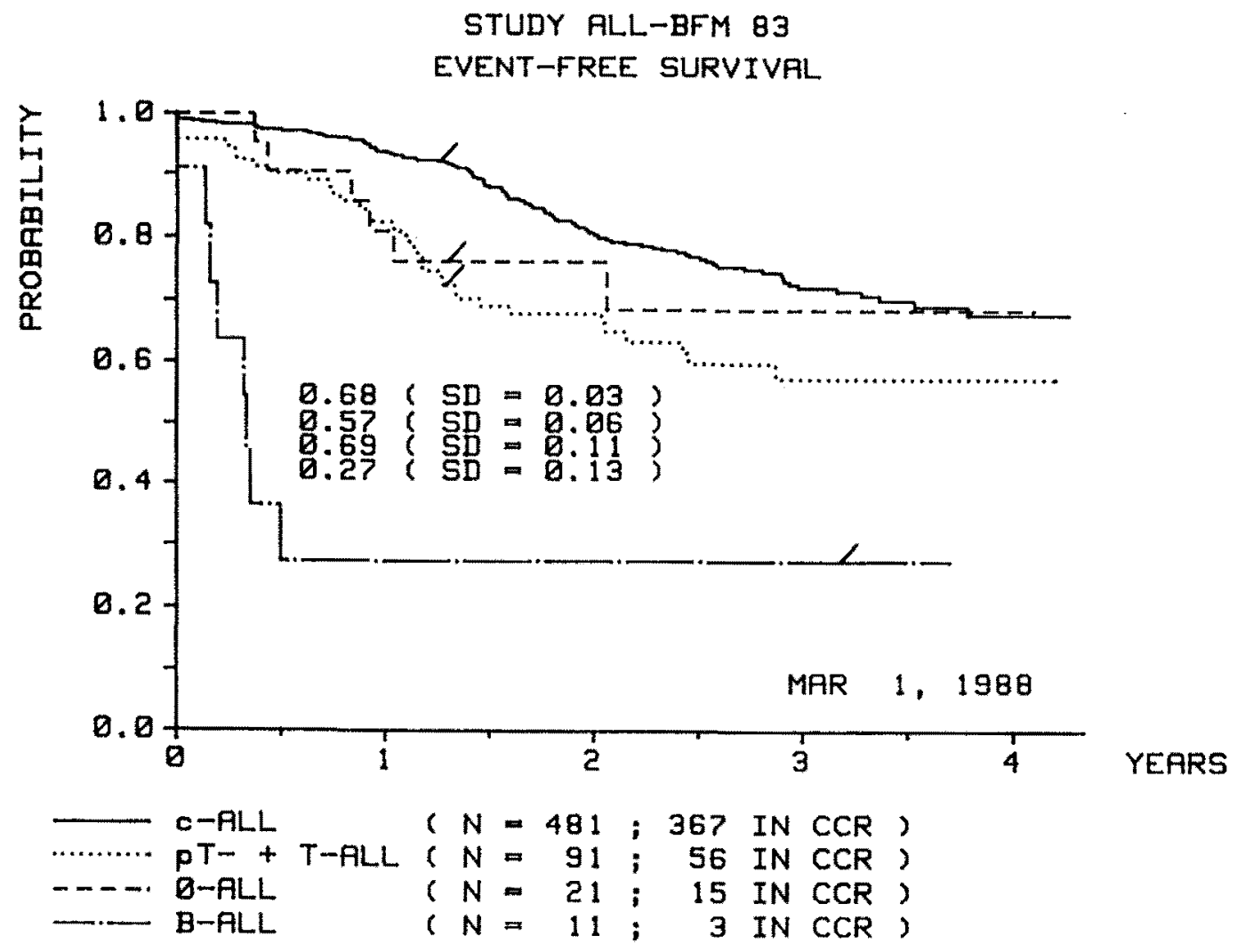

Fig. 1. Probability of event-free survival for 604 children with acute lymphoblastic leukemia $(A L L)$ according to immunophenotyping subgroups. Median follow-up time 27 months. Slashes indicate last patient entering the group, as in Fig. 2 and Fig. 3. P-values: c-ALL vs. pT-/T-ALL $<0.001$; cALL vs. O-ALL 0.5; cALL vs. B-ALL <0.0001; pT-/T-All vs. O-ALL 0.48; pT-/TALL vs. B-ALL $<0.001$; O-ALL vs. B-ALL 0.001. CCR, Continuous complete remission

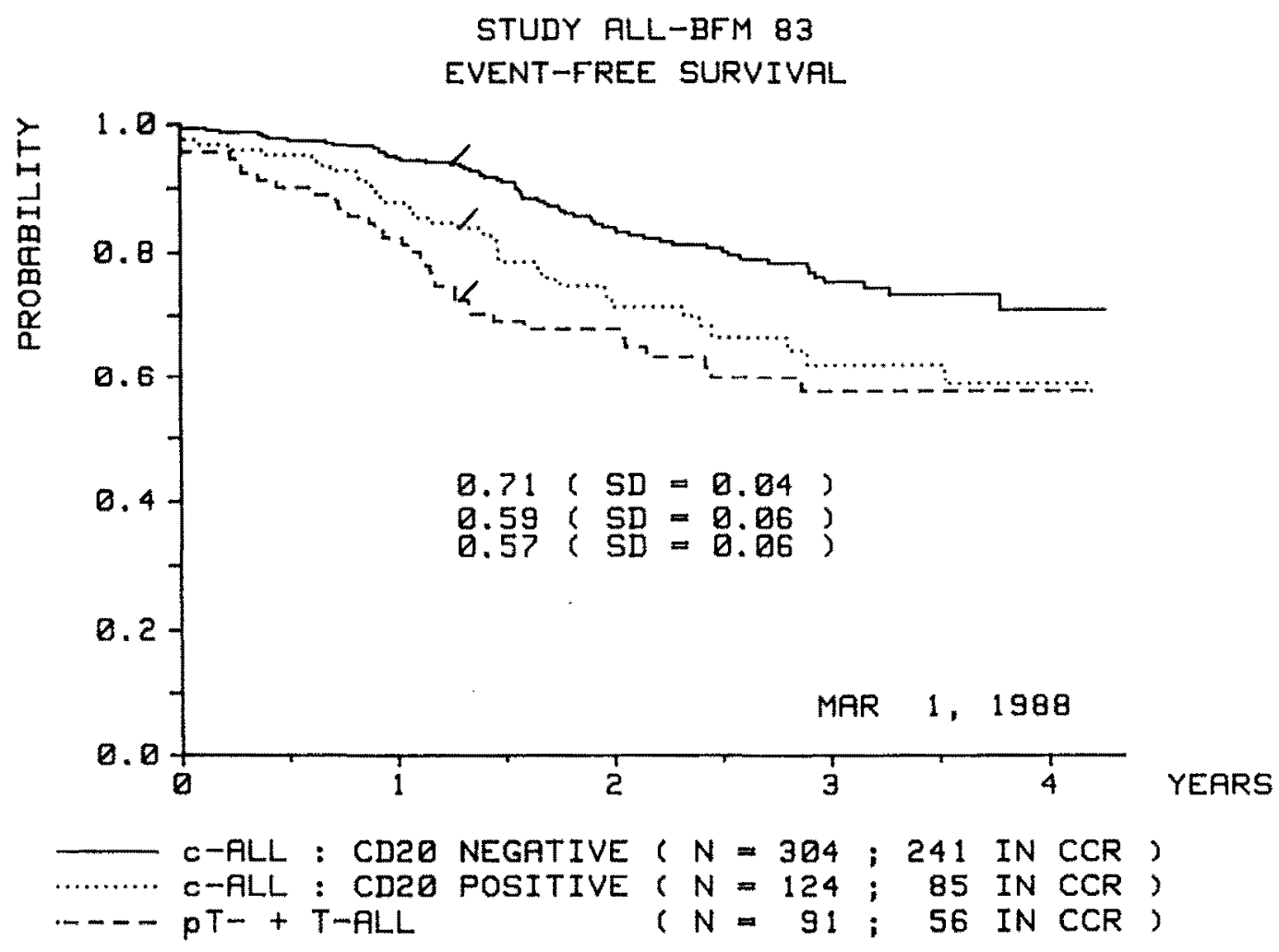

Fig. 2. Probability of event-free survival for patients with $\mathrm{CD} 20^{-} \mathrm{cALL}, \mathrm{CD} 20^{+} \mathrm{cALL}$, and pT-/T-ALL. $P$-values: CD20 ${ }^{-}$cALL vs. CD20 ${ }^{+}$cALL 0.004; $\mathrm{CD}^{-} 0^{-}$cALL vs. pT-/T-ALL $<0.0001 ; \mathrm{CD} 20^{+}$cALL vs. pT-/T-ALL 0.31. CCR, Continous complete remission 


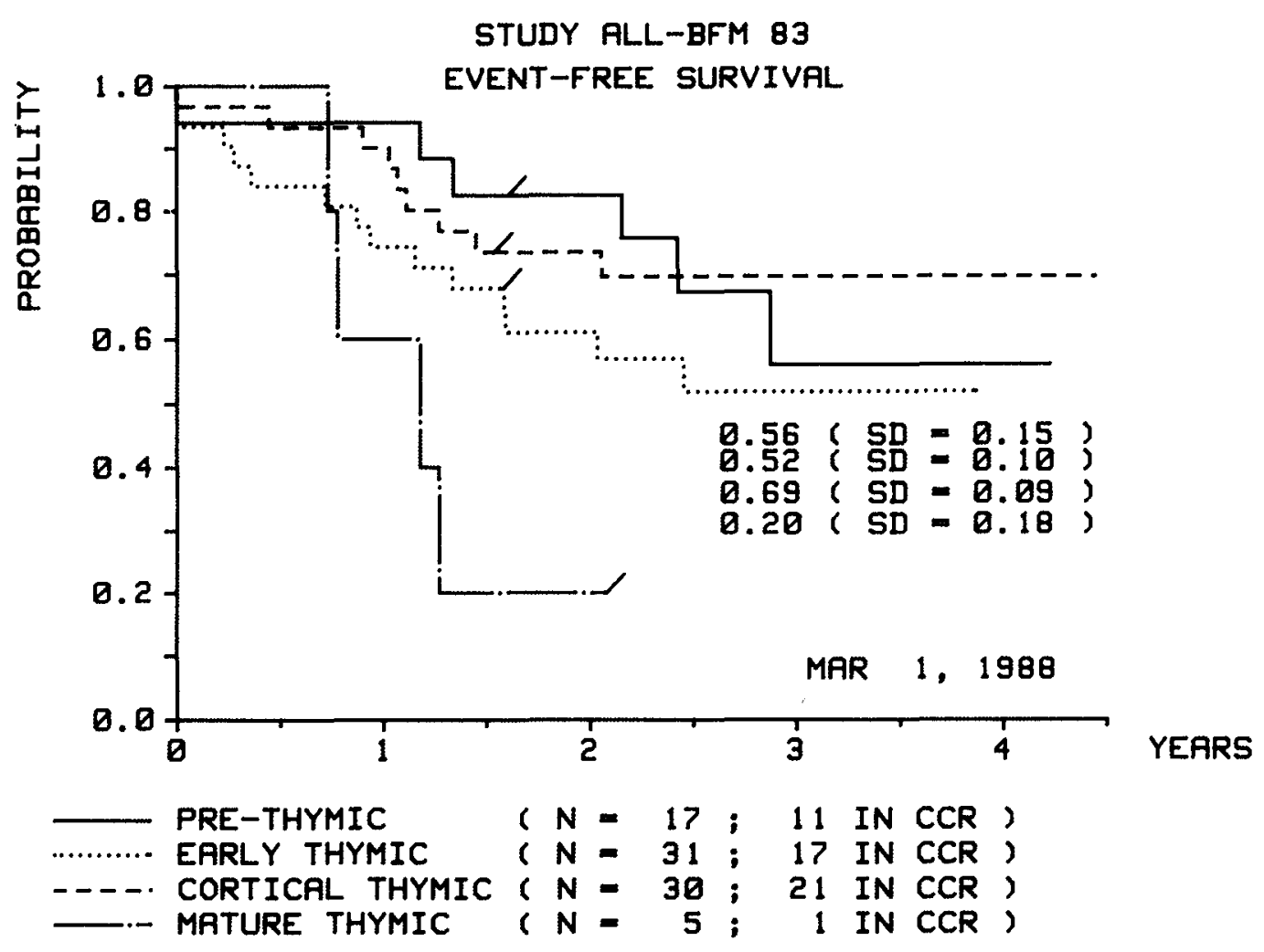

Fig. 3. Probability of event-free survival for patients with pre-thymic, early thymic, cortical thymic, and mature thymic T-ALL. $P$-values not significant. $C C R$, Continuous complete remission

Table 2. Clinical and hematological features of immunophenotypic subgroups at presentation

\begin{tabular}{lllllc}
\hline Feature & $\begin{array}{l}\text { Units } \\
(\%)\end{array}$ & $\begin{array}{l}\text { Null } \\
(n=21)\end{array}$ & $\begin{array}{l}\text { Common } \\
(n=481)\end{array}$ & $\begin{array}{l}\text { B } \\
(n=11)\end{array}$ & $\begin{array}{c}\text { Pre-T/T } \\
(n=91)\end{array}$ \\
\hline WBC $\left(\times 10^{9} / 1\right)$ & $\geq 50$ & 57.1 & 11.9 & 0 & 65 \\
Age (years) & $<1$ & 28.5 & 1 & 0 & 0 \\
& $1-<10$ & 28.6 & 81.9 & 72.7 & 61.5 \\
Sex (\% male) & $\geq 10$ & 42.9 & 17.1 & 27.3 & 38.5 \\
Platelets $\left(\times 10^{9} / 1\right)$ & & 47.6 & 53.8 & 90.9 & 70.3 \\
Hemoglobin $(\mathrm{g} / \mathrm{dl})$ & $<100$ & 57.1 & 74.2 & 45.5 & 70.3 \\
Splenomegaly & $<8.0$ & 57.1 & 62.6 & 18.2 & 17.5 \\
Hepatomegaly & & 57.1 & 35.6 & 27.3 & 69.2 \\
Mediastinal mass $(\%$ present) & 57.1 & 52.6 & 18.2 & 71.4 \\
Lympadenopathy (\% present) & 0 & 1.0 & 0 & 51.6 \\
CNS disease & 33.3 & 36.6 & 54.5 & 73.6 \\
\hline
\end{tabular}

a $\geq 4 \mathrm{~cm}$ below the costal margin

\section{Clinicopathological Features}

The clinical and hematological features of immunophenotypic subgroups at presentation are depicted in Table 2. Table 3 shows that there were pronounced clini- cal and hematological differences between common ALL and pre-T/T-ALL, whereas $\mathrm{CD} 20^{-}$and $\mathrm{CD} 20^{+}$common ALL did not differ significantly in their clinicopathological features. T-lineage immunophenotypic subgroups were sim- 
Table 3. Comparison of clinical and hematological features at presentation within major immunological subgroups

\begin{tabular}{|c|c|c|c|c|c|c|}
\hline \multirow{2}{*}{$\begin{array}{l}\text { Characteristics } \\
\text { analyzed }\end{array}$} & \multicolumn{4}{|c|}{ Phenotype } & \multicolumn{2}{|c|}{ Significance level ${ }^{\mathrm{a}}$} \\
\hline & $\begin{array}{l}\mathrm{CD} 20^{-} \\
\mathrm{cALL} \\
(n=304)\end{array}$ & $\begin{array}{l}\mathrm{CD} 20^{+} \\
\mathrm{cALL} \\
(n=124)\end{array}$ & $\begin{array}{l}\text { pre-T } \\
(n=18)\end{array}$ & $\begin{array}{l}\text { T-ALL } \\
(n=73)\end{array}$ & $\begin{array}{l}\mathrm{CD}^{2} 0^{-} \\
\text {cALLvCD20 } \\
\text { cALL }\end{array}$ & $\begin{array}{l}\text { cALL v } \\
\text { pre-T/ } \\
\text { T-ALL }\end{array}$ \\
\hline Age (median, years) & 4.5 & 3.9 & 9.4 & 8.0 & $N S^{b}$ & $P<.001$ \\
\hline $\begin{array}{l}\text { WBC } \\
\qquad\left(\text { median, } \times 10^{9} / 1\right)\end{array}$ & 9.9 & 11.8 & 65.0 & 94.4 & NS & $P<.001$ \\
\hline \multicolumn{7}{|l|}{ Risk group $^{c}(n)$} \\
\hline $\mathrm{SR}$ & 195 & 73 & 5 & 12 & NS & $P<.001$ \\
\hline MR & 98 & 50 & 7 & 35 & NS & $P<.01$ \\
\hline HR & 11 & 1 & 6 & 26 & NS & $P<.001$ \\
\hline Sex (\% male) & 54.9 & 53.2 & 66.6 & 71.2 & NS & $P=.004$ \\
\hline $\begin{array}{l}\text { Mediastinal mass } \\
\text { (\% present) }\end{array}$ & - & - & 50.0 & 52.1 & NS & $P<.001$ \\
\hline Hepatomegaly $^{d}(\%)$ & 54.6 & 50.8 & 72.2 & 71.2 & NS & $P=.001$ \\
\hline Splenomegaly $^{\mathbf{d}}(\%)$ & 39.1 & 37.1 & 72.2 & 68.5 & NS & $P<.001$ \\
\hline CNS disease $\quad(\%)$ & 1.3 & 1.6 & 5.5 & 11 & NS & $P<.001$ \\
\hline PAS (\% positive) & 70.1 & 60.5 & 28.8 & 31.5 & $P=.07$ & $P<.001$ \\
\hline $\begin{array}{l}\text { Acid phosphatase } \\
\text { ( } \% \text { positive) }\end{array}$ & 5.6 & 16.9 & 83.3 & 93.2 & $P<.001$ & $P<.001$ \\
\hline $\begin{array}{l}\text { a Pre-T and T-ALL } \\
\text { b NS, Not significant } \\
\text { - Total tumor load a } \\
\text { medium risk; HR, hig } \\
\text { d } \geq 4 \mathrm{~cm} \text { below costa }\end{array}$ & $\begin{array}{l}\text { gnosis } \\
\mathrm{k} \\
\text { gin }\end{array}$ & all chara & eristics & yzed & D & isk; MR, \\
\hline
\end{tabular}

ilar in their clinical and hematological features, whereas children with $\mathrm{CD} 10^{+}$ pre-T/T-ALL were slightly older, had lower leukocyte counts, and presented with thymic mass more often than the CD10- patients.

\section{Discussion}

In the light of the progress made in the immunophenotyping of ALL, several studies have attempted to identify immunological subtypes with differing prognoses, the long-term goal being to individualize therapy according to the leukemic immunophenotype [17].

Identification of immunophenotypic features with potential prognostic significance in the large common-ALL group is rather difficult due to the relatively low failure rate for these patients. Recently, however, the prognosis in precursor Bcell-lineage ALL has been correlated with cytoplasmic $\mu$ chain expression [5] and quantitative levels of CD10 expression [18]. Since cytoplasmic Ig was not generally investigated in this study, we selected the CD20 antigen for further subclassification of the common-ALL group and observed that the duration of EFS was shorter to a statistically significant degree for patients with $\mathrm{CD} 20^{+}$ common ALL than for those in the CD20- common-ALL subgroup. This difference could not be explained by unequal distribution of the two well-established clinical prognostic factors, age and initial leukocyte count, nor could it be ascribed to other significant differences 
of clinical characteristics among these subgroups, e.g., incidence of extramedullary involvement or initial CNS disease. Within the common-ALL group, Cox regression analysis revealed independent prognostic value for only three factors, i.e., WBC, hemoglobin level, and expression of the CD20 antigen. These data suggest that common-ALL subgroups of potential prognostic significance can be defined by monoclonal antibodies and that the prognosis in precursor B-cell-lineage ALL is related to the degree of maturity of the malignant cells. Reasons for the poorer treatment outcome of the $\mathrm{CD} 20^{+}$common-ALL patients are uncertain, and additional studies on the biological characteristics of this subgroup are necessary for clarification.

T-cell neoplasms have been categorized according to stages of normal differentiation into pre- $\mathrm{T}$, early, cortical or common, and mature thymocyte subtypes [19]. The potential clinical relevance of subset designation, however, has not yet been demonstrated among patients with T-cell-lineage ALL. In the ALL-BFM 83 study, children with pre$\mathrm{T} / \mathrm{T}$ immunophenotype did not differ significantly in their response to induction therapy from other immunophenotypical subgroups, but they had a significantly shorter duration of EFS than children with common ALL. The poorer treatment outcome of T-lineage ALL, however, was mainly related to the association with unfavorable clinical features, and the pre-T/T-ALL phenotype did not retain independent prognostic significance in the multivariate model. Immunophenotypic subgroups of T-lineage ALL (i. e., pre-T vs. early vs. cortical vs. mature T-ALL) did not differ significantly with regard to clinical features, response to induction therapy, and EFS. Interestingly, four of five children in the small mature-T-cell subgroup relapsed within 16 months after diagnosis. The prognostic impact of this subgroup, however, has to be evaluated in larger series of patients. Furthermore, it should be empha- sized that eight patients with $\mathrm{T}$-lineage ALL did not fit into the T-cell-differentiation stages, indicating that any phenotypic categorization of T-lineage ALL is likely to be an oversimplification and does not reflect the real extent of heterogeneity of T-cell ontogeny. In contrast to a recent report from the Pediatric Oncology Group [20], the expression of CD10 within T-lineage ALL was not prognostically important in the ALL-BFM 83 study, but slight differences with regard to clinical features (age, WBC, mediastinal mass) were observed among CD10 ${ }^{+}$ and $\mathrm{CD} 10^{-}$pre-T/T-ALL patients.

In conclusion, our data confirm the reported incidence of immunophenotypic subgroups and the clinical usefulness of monoclonal-antibody phenotyping in childhood ALL. The expression of the CD20 antigen could be identified as an independent prognostic factor in patients with precursor B-cell-lineage ALL and may be important for risk assignment in future treatment planning. The poorer treatment outcome of T-lineage ALL can be explained largely by the association with unfavorable clinical factors. In contrast to results in adult ALL [21], immunophenotypic subgroups in childhood T-lineage ALL (i.e., pre-T vs. TALL) did not differ significantly with regard to clinicopathological features and clinical outcome. Further studies of immunological features in combination with characterization by lineage-associated molecular probes are needed to evaluate the clinical significance of subset designation within T-lineage ALL.

Acknowledgements. The authors are grateful to Drs. B. Dörken and W. Knapp for supplying their monoclonal antibodies. We also thank J. Weirowski for helpful suggestions in preparing this manuscript.

\section{References}

1. Foon KA, Todd RF (1986) Immunologic classification of leukemia and lymphoma. Blood 68:1-31

2. Hoffbrand AV, Drexler HG, Ganeshaguru K, Piga A, Wickremasinghe RG (1986) 
Biochemical aspects of acute leukaemia. In: Gale RP, Hoffbrand AV (eds) Acute leukaemia. Saunders, London, pp 669694

3. Whang-Peng J, Knutsen T (1987) The role of cytogenetics in the characterization of acute leukemia. Acute lymphoblastic leukemia and acute myeloblastic leukemia. In: Stass SA (ed) The acute leukemias. Biologic, diagnostic, and therapeutic determinants. Dekker, New York, pp 153-201

4. Graninger WB, Wright JJ, Felix CA, Korsmeyer SJ (1987) Characterization of acute leukemia using lineage-associated molecular probes. In: Stass SJ' (ed) The acute leukemias. Biologic, diagnostic, and therapeutic determinants. Dekker, New York, pp 299-325

5. Crist W, Boyett J, Roper M, Pullen J, Metzgar R, Van Eys J, Ragab A, Starling K, Vietti T, Cooper M (1984) Pre-B cell leukemia responds poorly to treatment: a Pediatric Oncology Group study. Blood 63:407-414

6. Wolff, LJ, Richardson ST, Neiburger JB, Neiburger RG, Irwin DS, Baehner RL (1976) Poor prognosis of children with acute lymphocytic leukemia and increased B-cell markers. J Pediatr 89:956-958

7. Sen L, Borella L (1975) Clinical importance of lymphoblasts with $\mathrm{T}$ markers in childhood acute leukemia. N Engl J Med 292: 828-832

8. Sallan SE, Ritz J, Pesando J, Gelber R, O'Brien C, Hitchcock S, Coral F, Schlossman SF (1980) Cell surface antigens: prognostic implications in childhood acute lymphoblastic leukemia. Blood 55:395-402

9. Greaves MF, Janossy G, Peto J, Kay H (1981) Immunologically defined subclasses of acute lymphoblastic leukaemia in children: their relationship to presentation features and prognosis. $\mathrm{Br} \mathrm{J}$ Haematol 48:179-197

10. Rivera G, Mauer AM (1987) Controversies in the management of childhood acute lymphoblastic leukemia: treatment intensification, CNS leukemia, and prognostic factors. Semin Hematol 24:12-26

11. Riehm H, Reiter A, Schrappe M, Berthold F, Dopfer R, Gerein V, Ludwig R, Ritter J, Stollmann B, Henze G (1987) Die Corticosteroid-abhängige Dezimierung der Leukämiezellzahl im Blut als Prognosefaktor bei der akuten lymphoblastischen Leukämie im Kindesalter
(Therapiestudie ALL-BFM 83). Klin Pädiatr 199: 151-160

12. Ludwig WD, Bartram CR, Ritter J, Raghavachar A, Hiddemann W, Heil G, Harbott J, Seibt-Jung H, Teichmann JV, Riehm H (1988) Ambiguous phenotypes and genotypes in 16 children with acute leukemia as characterized by multiparameter analysis. Blood 71:1518-1528

13. Hiddemann W, Ludwig WD, Herrmann F, Harbott J, Beck JD, Lampert F, Odenwald E, Riehm H (1986) New techniques in the diagnosis and pretherapeutic characterization of acute leukemias in children: analyses by flow cytometry, immunology and cytogenetics in the BFM studies. In: Riehm H (ed) Malignant neoplasms in childhood and adolescence. Karger, Basel, pp 106-127

14. Kaplan EL, Meier P (1958) Nonparametric estimation from incomplete observations. J Am Stat Assoc 53:457-481

15. Mantel N (1966) Evaluation of survival data and two new rank order statistics arising in its consideration. Cancer Chemother Rep 50:163-170

16. Cox DR (1972) Regression models and life tables. J R Stat Soc B 34:187-220

17. Pinkel D (1987) Curing children of leukemia. Cancer 59:1683-1691

18. Look AT, Melvin SL, Brown K, Dockter ME, Roberson PK, Murphy SB (1984) Quantitative variation of the common acute lymphoblastic leukemia antigen (gp100) on leukemic marrow blasts. J Clin Invest 73:1617-1628

19. Reinherz EL, Kung PC, Goldstein G, Levey RH, Schlossman SF (1980) Discrete stages of human intrathymic differentiation: analysis of normal thymocytes and leukemic lymphoblasts of T-cell lineage. Proc Natl Acad Sci USA 77:15881592

20. Dowell BL, Borowitz MJ, Boyett JM, Pullen J, Crist WM, Quddus FF, Russell EC, Falletta JM, Metzgar RS (1987) Immunologic and clinicopathologic features of common acute lymphoblastic leukemia antigen-positive childhood T-cell leukemia. Cancer 59:2020-2026

21. Thiel E, Kranz BR, Raghavachar A, Bartram CR, Löffler $H$, Messerer $D$, Ganser A, Ludwig WD, Büchner T, Hoelzer D (1989) Prethymic phenotype and genotype of pre-T (CD7+/ER - )-cell leukemia and its clinical significance within adult acute lymphoblastic leukemia. Blood 73:12471258 